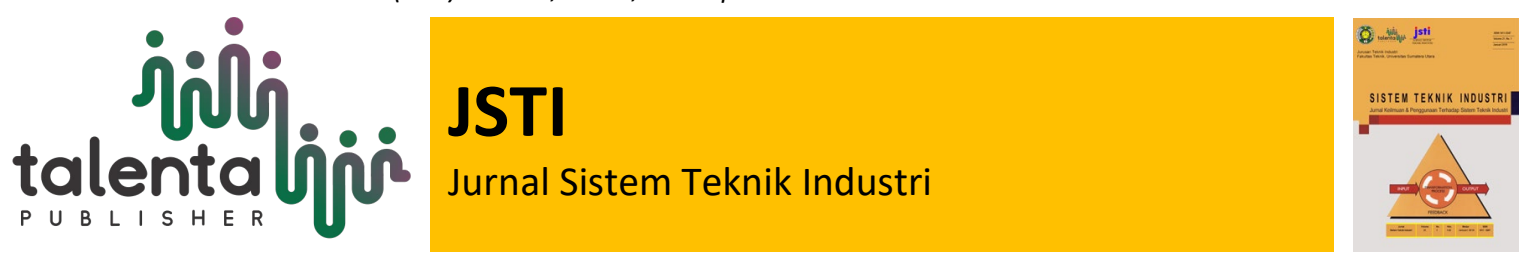

\title{
Analisis Penentuan Kriteria Kualitas Layanan Pengecatan Mobil
}

\section{Nofriani Fajrah1, Yogi Perdana1}

${ }^{1}$ Universitas Putera Batam, Indonesia

\begin{abstract}
Abstrak. Pertumbuhan kendaraan bermotor memberikan kesempatan kepada bisnis bengkel pengecatan mobil. Dewasa ini bisnis bengkel pengecatan mobil meningkat dan persaingan untuk memenuhi keinginan konsumen. Persaingan bisnis bengkel pengecatan mobil semakin ketat karena keinginan konsumen yang dinamis. Hal ini dikarenakan bisnis bengkel pengecatan mobil menawarkan pilihan jasa pengecatan sesuai dengan permintaan konsumen. Ogick Paint Art merupakan salah satu bengkel pengecatan mobil, perbaikan kendaraan dan modifikasi yang menerima hampir semua pengerjaan pengecatan seperti sepeda motor, mobil, dan aksesoris kendaraan bermotor lainnya. Tujuan dai penelitian ini adalah untuk mengidentifikasi bagaimana memperoleh kriteria kualitas yang sesuai dengan keinginan konsumen menggunakan kuesioner Voice of Customer (VoC). Data yang telah diperoleh dari kuesioner Voice of Customer ( $\mathrm{VoC}$ ) kemudian akan digunakan sebagai panduan dalam membangun House of Quality (HoQ). Berdasarkan perhitungan House of Quality (HoQ) diketahui bahwa kriteria kualitas yang memiliki nilai prioritas paling tinggi adalah daya tahan kilap dan daya tahan intensitas warna yang memperoleh nilai 5 dari nilai tingkat kepentingan konsumen. Sedangkan peringkat kepentingan spefikasi teknis tertinggi adalah 251.29 dengan nilai kepentingan absolut dan nilai kepentingan relatif secara berutut-turut adalah 81,87 dan $7,23 \%$ untuk spesifikasi teknis kesesuaian rasio pernis dan hardener
\end{abstract}

Kata Kunci: House of Quality (HoQ), Kriteria Kualitas Pelayanan, Quality Function Deployment (QFD), Voice of Customer (VoC),

\begin{abstract}
The growth of motorized vehicles provides an opportunity for car painting workshop business. Today's car painting workshop business is increasing and competing to satisfy customers. Competition in the car painting workshop business is getting tougher because of the desire of dynamic customers. This is because the car painting workshop business is offers the choices according to customer's wishes. Ogick Paint Art is one of the car painting workshop business for painting, vehicle repairs and modifications that accepts almost all painting jobs such as motorcycles, cars, and other vehicle accessories. The purpose of this study is to find out how to get quality criteria in accordance with the customer's desires by using the Voice of Customer (VoC) questionnaire. Data obtained from the Voice of Customer (VoC) questionnaire was then used as a reference for building the House of Quality (HoQ). based on calculations in House of Quality (HoQ) it is known that the quality criteria has the highest priority value is the durability of glossy and durability of colour intensity are getting 5 of customer importance value. While the highest technical importance rating is 251.29 with absolute value importance and relative importance respectively 81.87 and $7.23 \%$ in the suitability ratio of varnish and hardener.
\end{abstract}

Keywords: Criteria of Service Quality, Quality Function Deployment (QFD), Voice of Customer (VoC), House of Quality (HoQ)

*Corresponding author at: Jl. R. Soeprapto 29422, Batam, Indonesia

E-mail address: nofriani@puterabatam.ac.id,yogiperdana.upb@gmail.com 
Received 9 July 2019 | Revised 23 July 2019 | Accepted 23 July 2019

\section{Introduction}

Meningkatkan pertumbuhan kendaraan bermotor memberikan peluang bagi bisnis jasa seperti bengkel cat. Bisnis layanan bengkel cat saat ini meningkat dan terus bersaing untuk unggul dalam memuaskan pelanggan. Namun, persaingan pangsa pasar dari bisnis jasa semakin ketat karena keinginan pelanggan yang dinamis. Ini karena bisnis toko cat menawarkan pilihan sesuai dengan keinginan pelanggan. Menurut data Badan Pusat Statistik tentang tingkat pertumbuhan kendaraan bermotor di Indonesia dari 2012 - 2016 adalah 26,83\% di mana tingkat pertumbuhan mobil penumpang adalah $8,73 \%$, bus $2,26 \%$, sepeda motor $8,32 \%$ dan sepeda motor $7,52 \%$. Bengkel Seni Lukis Ogick adalah salah satu bengkel yang bergerak dalam bidang melukis, memperbaiki dan memodifikasi kendaraan yang menerima hampir semua pekerjaan melukis kendaraan seperti sepeda motor, mobil, dan aksesori kendaraan lainnya baik dengan airbrush, water slide decal, atau metode melukis polos. Ogick Paint Art hanya menggunakan testimonial dari pelanggan dalam menjaga konsistensi kualitas lukisan yang dilakukan. Dengan demikian toko cat Ogick Paint Art mendapat kritik dan saran langsung dari pelanggan yang positif dan negatif. Namun, bengkel Ogick Paint Art belum memiliki kriteria kualitas standar sehingga tidak dapat meningkatkan kepuasan pelanggan. Dalam proses pengecatan mobil, cacat yang umumnya terjadi adalah kulit jeruk (kulit jeruk), meleleh (runs), keropos (pin holing), kehilangan daya rekat (Peeling), bergarisgaris ketika selesai dipoles (Tanda Poles), lebih tipis atau hardener tidak menyatu (Pop Pelarut), garis-garis yang disebabkan oleh partikel logam mengambang (Mottling), hilangnya gloss (anyaman), cat lama yang mengangkat atau melengkung (Lifting), menggelegak (Blistering), cracking (retak), warna yang bukan sama atau bergaris (Warna ketidakcocokan dan kerusakan yang membentuk seperti pulau dan menyusut (Penyusutan).

\section{Literature Review}

a. Menurut [19] merumuskan layanan adalah bahwa setiap tindakan atau kinerja yang ditawarkan oleh satu pihak ke pihak lain secara tidak berwujud tidak menyebabkan pengalihan kepemilikan. Produksinya dapat terkait dan juga tidak dapat dikaitkan dengan produk fisik. Sedangkan Berry, seperti dikutip oleh [9] mendefinisikan layanan sebagai perbuatan (tindakan, prosedur, kegiatan) proses dan bekerja untuk yang tidak berwujud. Merumuskan layanan sebagai kegiatan ekonomi yang memiliki sejumlah elemen tidak berwujud (nilai atau manfaat) yang terkait dengannya, yang melibatkan sejumlah interaksi dengan pelanggan atau dengan properti, tetapi tidak mengakibatkan transfer kepemilikan. Perubahan dalam kondisi dapat muncul dan produksi suatu layanan mungkin atau mungkin tidak memiliki koneksi dengan produk fisik. Layanan pasti adalah kegiatan yang dapat ditawarkan oleh satu pihak ke pihak lain, yang pada dasarnya tidak berwujud dan tidak mengakibatkan kepemilikan apa pun, dan produksi layanan mungkin terkait atau mungkin tidak terkait dengan fisik [12]. Komponen layanan dapat menjadi bagian kecil atau bagian utama dari keseluruhan penawaran. [12] membedakan penawaran sektor ini menjadi lima kategori. Yang pertama disebut penawaran 
barang berwujud murni, yang persediaannya hanya terdiri dari barang nyata, dan tidak ada layanan yang menyertai produk yang ditawarkan. Keduanya disebut penawaran barang nyata disertai dengan layanan. Penawaran ini terdiri dari barang berwujud yang disertai oleh satu atau sejumlah layanan untuk meningkatkan daya tarik pelanggan. Menurut [19], "Kepuasan adalah perasaan senang atau kecewa seseorang yang dihasilkan dari membandingkan kinerja atau hasil yang dirasakan suatu produk dengan harapan. Jika kinerjanya tidak sesuai harapan, hasilnya tidak memuaskan. Jika cocok harapan, pelanggan puas atau senang ". Konsep QFD dibuat di Jepang pada tahun 1960 setelah Perang Dunia 2 selesai. Konsep QFD digunakan oleh Jepang untuk meniru produk. Seiring dengan perkembangan zaman, QFD digunakan untuk mengembangkan konsep produk baru dan bukan produk imitasi. rumah kualitas (HoQ). Matriks tersebut berisi kebutuhan pelanggan di sisi kiri dan karakteristik teknik di atas. Setiap bagian dari matriks berisi hal-hal penting. Matriks ini biasanya dikompilasi dan diselesaikan oleh tim. Gambar 1 menunjukkan bagian matriks rumah kualitas [11]. Metode QFD dibagi menjadi 7 tahap, yaitu:

a. Identifikasi dan tetapkan harapan pelanggan.

Langkah pertama dan penting dalam proses QFD adalah mengidentifikasi harapan pelanggan. Pada tahap ini, permintaan, harapan, dan keluhan diidentifikasi dan ditentukan. Proses mengidentifikasi harapan pelanggan dapat dilakukan melalui distribusi kuesioner [12] atau diskusi kelompok fokus [13]. Beberapa metode lain yang dapat digunakan untuk mengidentifikasi harapan pelanggan adalah panel pelanggan, wawancara terstruktur, wawancara tidak terstruktur, pengamatan pelanggan yang mendalam, daftar keluhan pelanggan, daftar pangkalan data perbaikan dan masukan dari staf penjualan [10].

b. Evaluasi Kompetitif Pelanggan

Pada tahap ini, penilaian strategis atau penilaian kompetitif dari setiap harapan pelanggan diuraikan dalam bentuk tabel. Pelanggan diminta untuk mengungkapkan persepsi mereka tentang kualitas produk dan pesaing perusahaan [16].

c. Menetapkan persyaratan teknis

Pada tahap ini, harapan pelanggan diterjemahkan ke dalam persyaratan teknis. Tujuannya adalah untuk menerjemahkan harapan setiap pelanggan menjadi satu atau lebih persyaratan teknis. Setiap persyaratan teknis harus dapat diukur dan memenuhi harapan pelanggan. Langkah 1 dan 2 dilakukan dengan menggunakan pertanyaan "apa" untuk pelanggan. Langkah 3 adalah kelanjutan dari langkah 1 dan 2 dengan menanyakan kata "bagaimana" pada harapan masing-masing pelanggan. Dengan kata lain, perusahaan harus menemukan cara untuk memenuhi harapan pelanggan [16]. 
d. Mencari hubungan antara persyaratan teknis

Atap HoQ dirancang korelasi silang atau korelasi antara item persyaratan teknis. Ada banyak kemungkinan untuk korelasi antara persyaratan teknis. Meningkatkan karakteristik atau persyaratan teknis dapat berdampak atau berkorelasi dengan karakteristik atau persyaratan teknis lainnya. Lingkaran ganda menunjukkan korelasi positif yang sangat kuat. Satu lingkaran menunjukkan korelasi positif yang lemah. Multiple cross menunjukkan korelasi negatif yang kuat. Salib tunggal menunjukkan korelasi negatif yang lemah [17].

e. Tentukan korelasi antara persyaratan teknis dan harapan atau persyaratan pelanggan.

Untuk membuat matriks korelasi antara persyaratan pelanggan dan persyaratan teknis, hubungan antara keduanya harus ditetapkan. Hubungan persyaratan ditentukan dengan menggunakan 3 kategori, kuat, sedang dan lemah. Kategori yang kuat adalah nilai yang dinyatakan adalah 9. Nilai kategori sedang adalah 3 . Nilai kategori yang lemah adalah 1 . Selain itu, kategori kekuatan korelasi juga dapat diekspresikan dengan menggunakan tanda [18].

f. Tentukan beratnya

Berat ditentukan untuk setiap persyaratan teknis. Berat adalah fungsi atau kombinasi dari tingkat minat pelanggan dan kekuatan hubungan. Beratnya ini adalah hasil dari penggandaan antara kekuatan dan kepentingan [15].

g. Perencanaan kualitas

Setelah perhitungan bobot dilakukan, langkah pertama yang harus dilakukan adalah meningkatkan persyaratan teknis, atau sumber daya, perlu dikonsentrasikan sesuai persyaratan teknis. [15]. Uji kecukupan data dilakukan untuk menemukan data sampel telah diambil cukup untuk mewakili populasi. Yang ideal adalah melakukan pengukuran / pengamatan yang cukup banyak. Namun, ini tidak mungkin mengingat faktor waktu, energi dan biaya. Dengan menggunakan rumus sebagai berikut:

$$
\mathrm{N}=\frac{\mathrm{k} / \mathrm{s} \sqrt{\mathrm{N} \sum \mathrm{x}^{2}-\left(\sum \mathrm{x}\right)^{2}}}{\sum \mathrm{x}} \ldots \ldots \ldots \ldots
$$

Keterangan :

k : Tingkat Kepercayataan

s : Derajat Ketelitian

$\mathrm{N} \quad$ : Jumlah data observasi

$\mathrm{N}^{\prime}$ : Jumlah data teoritis

$\mathrm{x} \quad$ : data observasi 
Jika $\mathrm{N} ' \leq \mathrm{N}$ maka data dianggap memadai, tetapi jika $\mathrm{N}^{\prime}>\mathrm{N}$ data tidak cukup (kurang) dan perlu menambahkan data.

\section{Metode Penelitian}

Tujuan dari penelitian ini adalah untuk mengetahui bagaimana mendapatkan kriteria kualitas sesuai dengan keinginan pelanggan dengan menggunakan kuesioner Voice of Customer (VoC). Penelitian ini dilakukan di Ogick Paint Art yang berlokasi di Batu Besar RT 04 RW 01 No. 14 Ex. Nongsa - Batam. Variabel independen dari penelitian ini adalah keinginan pelanggan.

Sedangkan variabel dependen dalam penelitian ini adalah kriteria kualitas pengecatan mobil. Populasi penelitian ini adalah semua pelanggan bengkel yang melukis Ogick Paint Art, yaitu sebanyak 45 pelanggan. Teknik pengambilan sampel penelitian ini menggunakan teknik pengambilan sampel acak sederhana di mana semua anggota populasi memiliki kemungkinan yang sama untuk dijadikan sampel. Rumus yang digunakan dalam menentukan jumlah sampel menggunakan metode Slovin sebagai berikut:

$$
\mathrm{n}=\frac{\mathrm{N}}{1+\left(\mathrm{N}_{\mathrm{e}} \mathrm{e}^{2}\right)}
$$

Keterangan :

n: Jumlah Sampel

N: Total Populasi

e: Tingkat kepercayaan

Penelitian ini dilakukan dengan observasi langsung, diskusi dan kuesioner VoC. Pengamatan dan diskusi langsung dilakukan untuk mendapatkan informasi tentang kriteria kualitas yang diinginkan oleh responden. Setiap responden diminta memberikan pernyataan tentang kriteria kualitas pengecatan mobil yang diinginkan. Semua pernyataan kriteria kualitas yang diperoleh kemudian direkapulasi dan dikelompokkan untuk membuat kuesioner VoC. Kuisioner VoC digunakan untuk mengidentifikasi tingkat prioritas atau kepentingan setiap kriteria kualitas lukisan mobil yang dipilih. Skor skor pada kuesioner VoC menggunakan skala Likert, mulai dari 1 hingga 5. Data yang telah dikumpulkan akan dianalisis untuk dapat memperoleh hasil penelitian yang telah dilakukan. Metode analisis data menggunakan metode Quality Function Deployment (QFD) di mana langkah-langkahnya adalah:

a. Pengumpulan data kriteria kualitas lukisan mobil dengan mengidentifikasi kriteria kualitas lukisan mobil melalui pengamatan langsung dan diskusi kepada responden.

b. Pengelompokan kriteria kualitas lukisan dari rekapitulasi identifikasi kriteria kualitas lukisan mobil yang diberikan oleh responden. 
c. Pengumpulan data kuesioner Voice of Customer ( $\mathrm{VoC}$ ) ditunjukkan dengan mengisi nilai prioritas untuk setiap kriteria kepada 36 responden sesuai dengan perhitungan sampling.

d. Hasil kuesioner VoC kemudian direkapitulasi dan uji kecukupan data dilakukan.

e. Memproses data dari kuesioner Suara Pelanggan ( $\mathrm{VoC}$ ) pada nilai-nilai prioritas dengan menghitung nilai rata-rata.

f. Mengembangkan House of Quality (HoQ)

Adapun persiapan House of Quality (HoQ) ada beberapa variabel pendukung sebagai berikut:

a. Kompilasi atribut persyaratan pelanggan Data ini diperoleh dari hasil pengumpulan data kuesioner dari Voice of Customer. 10 atribut persyaratan pelanggan diperoleh.

b. Persiapan spesifikasi teknis

Data ini disusun berdasarkan hasil persiapan setiap atribut persyaratan pelanggan. Berdasarkan 10 atribut persyaratan pelanggan, 21 spesifikasi teknis diperoleh. Penentuan matriks hubungan antara atribut persyaratan pelanggan dengan spesifikasi teknis. Atribut persyaratan pelanggan yang telah diperoleh akan diukur sehubungan dengan spesifikasi teknis. Hubungan antara keduanya terdiri dari 3 kriteria, yaitu:

- Full Black Circle: Hubungan Kuat: 9

○ Blank Black Circle: Hubungan Menengah: 3

$\Delta$ Empty Triangle: Hubungan Lemah: 1

Penentuan matriks korelasi antara satu spesifikasi teknis dengan spesifikasi teknis lainnya.

Korelasi antara satu spesifikasi teknis dan spesifikasi teknis lainnya terdiri dari 3 kriteria, yaitu:

++ : Korelasi Kuat

$+\quad$ : Korelasi Lemah

- $\quad$ : Tidak ada Korelasi

c. Kompilasi matriks penilaian terhadap kriteria persyaratan pelanggan untuk pesaing. Kriteria untuk persyaratan pelanggan yang telah diperoleh adalah kriteria kualitas yang akan dinilai oleh pelanggan (responden) pada layanan yang dimiliki oleh pesaing.

d. Persiapan matriks penilaian spesifikasi teknis layanan untuk pesaing Spesifikasi teknis layanan yang dimiliki oleh pesaing juga dinilai berdasarkan kemampuan pesaing untuk memenuhi kriteria kualitas layanan yang diinginkan oleh pelanggan. 
e. Penentuan prioritas dengan menghitung nilai Absolute Importance (AI) dan Relative Importance (RI) Penentuan kepentingan mutlak dan kepentingan relatif adalah menentukan respons teknis yang memiliki prioritas untuk diterapkan terlebih dahulu. Absolute Importance (AI) adalah parameter yang menunjukkan prioritas untuk dilakukan, dengan melihat hubungan antara respons teknis, persyaratan pelanggan, dan tingkat minat pelanggan. Absolute Importance $(\mathrm{AI})=$ Total Importance level yang terkait dengan respons teknis terhadap nilai hubungan. Pentingnya Relatif adalah nilai kepentingan mutlak yang dinyatakan oleh persentase kumulatif. Relatif Pentingnya (RI) = (nilai AI untuk 1 item Respon Teknis) / (Total dari AI untuk semua Respon Teknis).

\section{Hasil dan Pembahasan}

Identifikasi kriteria kualitas dilakukan dengan observasi langsung dan metode diskusi. Pengamatan dan diskusi langsung dilakukan untuk mendapatkan informasi tentang kriteria kualitas yang diinginkan oleh pelanggan. Semua pernyataan kriteria kualitas yang diperoleh dari pengamatan dan diskusi langsung dengan pelanggan kemudian direkapitulasi dan dikelompokkan untuk membuat kuesioner VoC.

a. Kuesioner VoC

Berdasarkan hasil identifikasi kriteria kualitas pengecatan mobil dengan mengamati kuesioner VoC dapat disiapkan. Kuisioner VoC digunakan untuk mengidentifikasi tingkat prioritas atau minat yang diharapkan dari masing-masing kriteria kualitas lukisan untuk mobil yang dipilih. Skor skor pada kuesioner VoC menggunakan skala Likert, yaitu skala 1 sampai 5. Tabel 1 menunjukkan hasil kuesioner VoC yang dilakukan dengan observasi. 
Table 1 Kuisioner Suara Pelanggan.

\begin{tabular}{|c|c|c|c|}
\hline \multirow[b]{2}{*}{ No } & & \multirow{2}{*}{ Kriteria untuk Kualitas Lukisan Pilihan } & Priority Level \\
\hline & & & 12345 \\
\hline 1 & & Ketahanan Intensitas Warna & \\
\hline 2 & Warna & Aplikasi Warna Tidak Mengupas & \\
\hline 3 & & Pemilihan Warna Sesuai & \\
\hline & & Permintaan Pelanggan & \\
\hline 4 & & Daya tahan dempul & \\
\hline 5 & Dempul & $\begin{array}{l}\text { Putty sesuai dengan Kontur Bodi } \\
\text { Mobil }\end{array}$ & \\
\hline 6 & & Glossy Tahan Lama & \\
\hline 7 & Pernis & Pernis Tahan Gores & \\
\hline 8 & & $\begin{array}{l}\text { Hasil pengecatan tidak mudah } \\
\text { terkelupas }\end{array}$ & \\
\hline 9 & Teknis & $\begin{array}{l}\text { Hasil pengecatan bebas } \\
\text { kontaminasi }\end{array}$ & \\
\hline 10 & & Detail yang bagus & \\
\hline
\end{tabular}

Informasi:

$1=$ Sangat bukan Prioritas $3=$ Prioritas $5=$ Sangat Prioritas

$2=$ Bukan Prioritas $4=$ Sangat Prioritas

Uji kecukupan data digunakan untuk menentukan bahwa jumlah sampel data yang diambil cukup untuk melakukan proses selanjutnya. Dalam tes ini persamaan Slovin digunakan. Hasil perhitungan menunjukkan $\mathrm{N}^{\prime}<\mathrm{N}$, lalu suara data pelanggan pada kriteria kualitas lukisan yang diinginkan oleh pelanggan cukup, yaitu $\mathrm{N}^{\prime}=19<\mathrm{N}=36$.

$\mathrm{k}=2 ; \mathrm{s}=5 \% \approx 0,05 ; \mathrm{N}=36$

$$
N^{\prime}=\frac{k / s \sqrt{N \sum x^{2}-\left(\sum x\right)^{2}}}{\sum x}-\left[\frac{\frac{2}{5} \sqrt{36 x 114,6-(114,6)^{2}}}{114,6}\right]=19,254 \approx 19
$$

b. Perhitungan Nilai Rata-rata dari setiap Kriteria Kualitas

Perhitungan nilai rata-rata untuk setiap kriteria kualitas yang diharapkan untuk pengecatan mobil didasarkan pada data pada VoC daftar pertanyaan. Data perhitungan ini akan menjadi nilai penting atau nilai prioritas di House of Quality untuk masing-masing kriteria kualitas sehingga nilai Absolute Improtenace (AI) dapat diketahui. Tabel 4.2 menunjukkan hasil menghitung nilai rata-rata dari setiap kriteria kualitas. Contoh Perhitungan: Nilai Rata-rata untuk warna yang tahan lama intensitas. Oleh karena itu, nilai prioritas untuk kriteria kualitas yang diinginkan untuk intensitas warna tahan lama adalah 5.

$$
\bar{X}=\frac{\sum_{i=i}^{n} X_{i}}{N}=\bar{X}=\frac{166}{36}=4,61 \approx 5
$$


c. House of Quality (HoQ)

\section{Spesifikasi Pelanggan}

Spesifikasi pelanggan atau persyaratan pelanggan berisi data atau informasi terstruktur tentang kebutuhan pelanggan dan keinginan berdasarkan hasil penelitian dari kuesioner VoC pada kriteria untuk kualitas layanan lukisan di Ogick Workshop melukis Seni Lukis. Berdasarkan hasil pengumpulan data dapat diidentifikasi pentingnya pelanggan spesifikasi untuk setiap kriteria kualitas lukisan yang diharapkan / diinginkan oleh pelanggan (responden) menggunakan VoC daftar pertanyaan.

\section{Tanggapan teknis}

Tanggapan teknis terdiri dari karakteristik teknis untuk dapat memenuhi spesifikasi pelanggan dari suara pelanggan, bisa diatur dengan bantuan model "What vs How". Tanggapan teknis dari spesifikasi pelanggan ditunjukkan pada Tabel 3. Berdasarkan hasil analisis 21 tanggapan teknis diperoleh untuk setiap spesifikasi pelanggan.

Table 2 Kebutuhan Fungsional

\begin{tabular}{cc}
\hline No & Kebutuhan Fungsional \\
\hline 1 & Kesesuaian untuk pemilihan pigmen cat \\
2 & Teknik melukis dilakukan dengan benar dan merata \\
3 & Ketebalan setiap lapisan sama \\
4 & Mencampur pigmen yang tepat \\
5 & Memberikan sampel warna dengan beberapa varian \\
6 & Perbandingan antara dempul dan pengeras yang cocok \\
7 & Persiapan yang baik dari permukaan yang akan dempul \\
8 & Teknik dempul yang benar \\
9 & Gunakan peralatan yang sesuai \\
10 & Teknik pengamplasan yang benar \\
11 & Gunakan bahan pernis yang sesuai \\
12 & Teknik aplikasi pernis yang tepat \\
13 & Suhu yang tepat pada saat menerapkan pernis \\
14 & Perbandingan pernis dan pengeras sesuai \\
15 & Tekanan udara yang tepat \\
16 & Aplikasi pelapis keramik \\
17 & Gunakan primer atau epoksi sebelum dan sesudah mendempul \\
18 & Waktu pengecatan yang tepat untuk setiap lapisan \\
19 & Pekerjaan dilakukan dengan hati-hati \\
20 & Pelukis yang berpengalaman \\
21 & Lukisan dilakukan di gerai lukisan \\
\hline
\end{tabular}

Hubungan Spesifikasi Pelanggan dengan Tanggapan Teknis Berdasarkan hasil analisis hubungan antara spesifikasi pelanggan dan respons teknis, kita tahu hubungan dengan tiga kriteria. Korelasi Respon Antar-Teknis Berdasarkan hasil identifikasi tanggapan teknis terhadap spesifikasi pelanggan untuk menemukan kriteria pelanggan, perlu untuk mengidentifikasi korelasi antara tanggapan teknis. Korelasi antara respons teknis menunjukkan langkah perusahaan dalam menjalankan proses atau memberikan layanan kepada pelanggan. 


\section{Prioritas Respon Teknis}

Berdasarkan hasil evaluasi hubungan antara spesifikasi pelanggan dan respons teknis, dapat ditentukan kepentingan absolut dan relatif untuk setiap respons teknis. Contoh perhitungan untuk Respon Teknis:

Kesesuaian Pemilihan Pigmen Cat

Peringkat Penting Teknis $=$ Persentase Total Berat Relatif Kebutuhan Pelanggan $\mathrm{x}$ Nilai Hubungan Setiap Kriteria

$\mathrm{TIR}=[(14 \% \times 9)+(10 \% \times 3)+(13 \% \times 1)] \times 100=166,73$

Absolute Importance $(\mathrm{AI})=$ Total dari tingkat Importance yang terkait dengan respons teknis terhadap nilai hubungan.

$\mathrm{AI}=(5 \times 9)+(3 \times 3)+(4 \times 1)=58$

Relatif Penting $(\mathrm{RI})=($ Nilai AI untuk 1 item Tanggapan Teknis $) /($ Total dari AI untuk semua Tanggapan Teknis)

$\mathrm{RI}=58 / 1132 \times 100 \%=4,8 \%$

\section{Target Teknis}

Target teknis menunjukkan hasil evaluasi kualitas rumah dari respons teknis terhadap spesifikasi pelanggan. Target teknis ini harus dipertimbangkan oleh perusahaan dalam meningkatkan kualitas layanan.

\section{d. Pembahasan}

Berdasarkan penelitian yang telah dilakukan dengan desain House of Quality dalam menentukan kriteria kualitas untuk bisnis bengkel seni lukis Ogick Paint Art. Hasil penelitian menunjukkan bahwa kriteria kualitas layanan yang memiliki prioritas tertinggi adalah intensitas warna daya tahan dan kilau daya tahan. Nilai kepentingan pelanggan untuk dua kriteria kualitas tertinggi adalah 5. Intensitas warna daya tahan adalah salah satu kriteria kualitas tertinggi karena mempengaruhi kemampuan keuangan pelanggan untuk mengecat berulang kali. Semakin kuat tingkat intensitas warna, pelanggan dapat menghemat anggaran untuk melukis. Di sisi lain, kilau daya tahan adalah salah satu kriteria kualitas tertinggi karena mempengaruhi hasil estetika lukisan. Semakin kuat daya kilap, semakin tinggi nilai estetika hasil lukisan bagi pelanggan. Sedangkan kriteria kualitas layanan yang memiliki prioritas terendah adalah pernis anti gores yang sama dengan 1. Hal ini disebabkan oleh kenyataan bahwa saat ini terdapat pelapis kualitas tambahan, yaitu pelapis keramik. Berdasarkan penelitian, juga diketahui bahwa peringkat kepentingan teknis tertinggi adalah 251,29 dengan kepentingan absolut dan kepentingan relatif, masing-masing 81,87 dan 7,23\%. Sedangkan nilai peringkat kepentingan teknis terendah adalah 
53.267 dengan nilai kepentingan absolut dan kepentingan relatif masing-masing 17,35 dan 1,53\%. Peringkat kepentingan teknis tertinggi adalah untuk respons teknis dari perbandingan pernis dan pengeras yang sesuai. Ini karena kurangnya pengeras saat pencampuran, hasil pernis menjadi lunak dan kering lama. Sementara peringkat kepentingan teknis terendah adalah untuk respons teknis tekanan udara yang sesuai. Hal ini disebabkan oleh tekanan udara yang tidak mempengaruhi kualitas pengecatan.

\section{Kesimpulan}

Berdasarkan hasil penelitian, dapat dilihat bahwa kriteria kualitas layanan dengan menggunakan Voice of Customer (VoC) dalam bisnis bengkel pengecatan mobil untuk bengkel pengecatan Ogick Paint Art. Kriteria kualitas layanan yang diinginkan oleh pelanggan adalah daya tahan gloss dengan nilai kepentingan pelanggan 5 dan intensitas daya tahan intensitas warna dengan nilai kepentingan pelanggan 5. Sementara kriteria kualitas layanan yang memiliki nilai kepentingan pelanggan terendah adalah anti gores pernis sama dengan $1 \mathrm{Hal}$ ini disebabkan oleh kenyataan bahwa saat ini ada pelapis berkualitas tambahan, yaitu pelapis keramik. Berdasarkan penelitian, diketahui bahwa peringkat kepentingan teknis tertinggi adalah 251,29 dengan kepentingan absolut dan kepentingan relatif, masing-masing 81,87 dan 7,23\% dalam rasio yang sesuai dari pernis dan pengeras. Sementara itu, peringkat kepentingan teknis terendah adalah 53.267 dengan kepentingan absolut dan kepentingan relatif masing-masing 17,35 dan 1,53\% pada tekanan udara yang tepat.

\section{REFERENSI}

[1] Akbar, R, S Noor, and W Shah. 2010. "Qfd As a Tool for Improvement of Car Dashboard." Journal of Quality and Technology Management VI(1): 1-22.

[2] Baran, Züleyhan, and Mehmet Selami Yıldız. 2015. "Quality Function Deployment and Application on a Fast Food Restaurant." 6(9): 122-31.

[3] Jahanzaib, Mirza, Ahmad Wasim, Salman Hussain, and Haris Aziz. 2016. "A Framework for Implementing Quality Function Deployment (QFD ) for Utility Services." IOSR Journal of Business and Management 18(4): 92-99.

[4] Masui, Keijiro, Tomohiko Sakao, Mitsuru Kobayashi, and Atsushi Inaba. 2003. "Applying Quality Function Deployment to Environmentally Conscious Design." International Journal of Quality and Reliability Management 20(1): 90-106.

[5] Matorera, Douglas. 2015. "A Conceptual Analysis of Quality in Quality Function Deployment-Based Contexts of Higher Education.” 6(33): 145-56.

[6] Mehrjerdi, Yahia Zare. 2010. "Applications and Extensions of Quality Function Deployment." Assembly Automation 30(4): 388-403.

[7] Premkumar, D, and M Balamurugan. 2014. "Implementation of Quality Function Deployment in Pump Industry." International Journal of Innovative Research in Science, Engineering and Technology 3(3): 1258-62. 
[8] Sugianto, Welly, and Rony Prasetyo. 2018. "Jurnal Optimasi Sistem Industri Penerapan Quality Function Deployment ( QFD ) Pada Pengembangan Produk Sabun Di UKM Kota Batam.” 1: 86$100[1]$.

[9] Zeithaml, V.A. and Bitner, M.J. (2000) Services Marketing: Integrating Customer Focus across the Firm. 2nd Edition, McGraw-Hill, Boston.

[10] S. Zaim and Ş. Mehmet, "The Methodology of Quality Function Deployment with Crisp and Fuzzy Approaches and an Application in the Turkish Shampoo Industry,” J. Econ. Soc. Res., vol. 4, no. 1, pp. 27-53, 2012.

[11] E. S. Jaiswal, “A Case Study on Quality Function Deployment ( QFD ),” IOSR J. Mech. Civ. Eng., vol. 3, no. 6, pp. 27-35, 2012.

[12] C. Homkhiew, T. Ratanawilai, and K. Pochana, "Application of a quality function deployment technique to design and develop furniture products," Songklanakarin J. Sci. Technol, vol. 34, no. 6, pp. 663-668, 2012.

[13] B. Cerit, G. Küçükyazıcı, and G. Kalem, “Quality Function DOI: 10.25077/josi.v17.n1.p86-100.2018 Deployment and Its Application on a Smartphone Design,” Bakcan J. Electr. Comput. Eng., vol. 2, no. 2, pp. 86-91, 2014.

[14] Ö. Erkarslan and H. Yilmaz, "Optimization of Product Design Through Quality Function Deployment and Analytical Hierarchy Process : Case Study of A Ceramic Washbasin,” Metu JFA, vol. 1, no. 28, pp. 1-22, 2011.

[15] N. Vorasaiharit and N. Thawesaengskulthai, "Integration of SERVQUAL Model with Quality Function Deployment to enhance Library 's Service Quality,” Int. Conf. Eng. Technol. Big Data Anal. Jan. 21-22, 2016 Bangkok, vol. 1, no. 1, pp. 78-84, 2016.

[16] D. Kelesbayev, K. Kalykulov, Y. Yertayev, A. Turlybekova, and A. Kamalov, “A case study for using the quality function deployment method as a quality improvement tool in the universities," Int. Rev. Manag. Mark., vol. 6, no. 3, pp. 569-576, 2016.

[17] Z. Baran and M. S. Y1ld1z, "Quality Function Deployment and Application on a Fast Food Restaurant,” Int. J. Bus. Soc. Sci., vol. 6, no. 9, pp. 122-131, 2015.

[18] Kotler, Philip dan Keller, Kevin Lane. (2004), Manajemen Pemasaran 2, Edisi Milenium, Jakarta: PT. Ikrar Mandiri.

[19] Kotler and Keller. (2012) Manajemen pemasaran. Edisi 12. Jakarta : Erlangga.

[20] Kotler, Philip \&Armstrong, Gary (2014). Prinsip-prinsip Manajemen. Edisi 14, Jilid 1. Jakarta: Erlangga.

[21] Kotler, Philip. (2008). Manajemen Pemasaran. Edisi12 Jilid 2. Jakarta: Indeks. 